\title{
EVALUASI MANAJEMEN LAYANAN SERVICE DESK PADA CUSTOMER CARE CENTER (C3) UIN SUSKA RIAU MENGGUNAKAN FRAMEWORK COBIT 4.1 DAN ITIL V3
}

\author{
Megawati \\ Program Studi Sistem Informasi, Fakultas Sains dan Teknologi \\ Universitas Islam Negeri Sultan Syarif Kasim Riau, \\ Email : mega.zahara@uin-suska.ac.id
}

\begin{abstract}
ABSTRAK
Makalah ini membahas tentang Evaluasi Kinerja Pengelolaan Customer Care Center (C3) di Pusat Teknologi Informasi Dan Pangkalan Data (PTIPD) Uin Suska Riau menggunakan Cobit 4.1 dan ITIL V3. Permasalahan di C3 tentang kinerja layanan TI antara lain pelayanan diberikan oleh yang bukan ahlinya, dalam hal ini siswa magang, ruangan yang sempit karena bergabung dengan 4 ATM, kurangnya SDM, serta kurang monitoring dari pimpinan terhadap pengendalian internalnya. Domain yang digunakan untuk mengevaluasi layanan adalah DS8 (Delivery dan Support 8 manage service desk). Teknik pengambilan sampel menggunakan diagram RACI (Responsible, Accountable, Consulted and Informed) sebanyak 9 orang. Teknik analisis yang digunakan untuk mengolah data menggunakan software Cobit Maturity Level Calculation. Pengelolaan kinerja TI C3 Uin Suska Riau pada saat ini (as is) berada pada level 2 yaitu Repeatable but intutitive dan berarti Proses pengelolaan TI sudah dikembangkan. manajemen telah memiliki pola untuk melakukan proses pengelolaan berdasarkan pengalaman berulang yang pernah dilakukan sebelumnya. Prosedur belum terstandarisasi dan tanggung jawab proses tata kelola diserahkan kepada individu masing-masing. Agar proses menjadi lebih baik maka diberikan tindakan berupa usulan perbaikan untuk setiap proses. Berdasarkan hasil evaluasi maka diberikan rekomendasi untuk perbaiki manajemen berdasarkan COBIT 4.1 dan ITIL V3.
\end{abstract}

Kata kunci : Cobit, Evaluasi, Maturity Level, ME, RACl.

\section{Pendahuluan}

Teknologi informasi (TI) saat ini sudah menjadi kebutuhan yang sangat penting bagi hampir semua organisasi karena dipercaya dapat membantu meningkatkan efektifitas dan efisiensi proses bisnis organisasi, termasuk didalamnya institusi pendidikan[1]. Untuk mencapai hal tersebut diperlukan suatu Monitoring dan Evaluasi kinerja TI agar keberadaan TI mampu untuk menunjang kesuksesan organisasi dalam pencapaian tujuannya.

Universitas Islam Negeri Sultan Syarif Kasim Riau (UIN Suska Riau) sebagai lembaga pendidikan yang mengemban tridharma perguruan tinggi (pengajaran, penelitian dan pengabdian kepada masyarakat) ikut berperan aktif dalam memajukan kesejahteraan umum. Universitas Islam Negeri Sultan Syarif Kasim Riau juga ikut berperan dalam mengembangkan dan menyiarkan islam. Dalam misinya UIN Suska Riau berupaya dalam mengembangkan ilmu pengetahuan, teknologi dan seni berbasis integrasi

keislaman. UIN Suska Riau sebagai lembaga pendidikan diharapkan dapat mengikuti perkembangan teknologi, terutama teknologi informasi guna menunjang proses tridharma perguruan tinggi, dan membangun sumber daya manusia yang berkualitas dan unggul dalam penyelengaraan pendidikan berkelas dunia (world class university). Jadi tidak hanya ilmu keislaman, namun juga ilmu pengetahuan dan teknologi guna merealisasikan konsep integrasi dan penunjang pencapaian visi misi UIN Suska Riau.

UIN Suska Riau juga salah satu perguruan tinggi yang menyediakan jasa di bidang pelayanan adalah Pusat Teknologi Informasi dan Pangkalan Data (PTIPD) Sebagai unit yang bertanggung jawab terhadap pengembangan dan implementasi teknologi informasi.

Pusat Teknologi Informasi dan Pangkalan Data (PTIPD) memberikan layanan IT Services di lingkungan kampus UIN Suska Riau, layanan PTIPD seperti, pendaftaran billing, infrastruktur jaringan, aplikasi terpadu, layanan internet, setifikasi/training. Selain itu PTIPD juga 
yang bertugas memastikan seluruh kondisi kinerja IT yang ada di Uin Suska Riau. PTIPD memberikan salah satu fasilitas pelayanan terkait ketersedian teknologi kepada mahasiswa, dosen dan pegawai di Uin Suska Riau yaitu customer care center (C3).

C3 di bentuk sejak Februari 2015 yang dikelola dibawah pimpinan Divisi Komunikasi dan Internet berfungsi sebagai pintu masuknya keluhan-keluhan pengguna dan menjadi penghubung antara pengguna dengan divisi-divisi yang bersangkutan untuk menyelesaikan permasalahan yang ada di civitas akademik dan Uin Suska Riau. Saat ini kinerja TI yang ada di C3 Uin suska Riau dianggap masih kurang efektif dan efesien karena dalam kinerja TI tidak terdapat proses yang mencakup pendefinisian indikator kinerja yang relevan, pelaporan kinerja yang sistematis dan tepat waktu, tindakan cepat atas penyimpangan dan belum efektif dan efesien pengendalian internal yang ada di Customer Care Center (C3) Uin Suska Riau.

Berdasaran hasil wawancara pada kepala PTIPD Uin Suska Riau Bapak Benny Sukma Negara, MT, wawancara kepada IT Helpdesk C3 Salti Realini Primasta,S.Kom, dan wawancara Manajer Divisi Komunikasi Dan internet Bapak Agus Surahmad,S.kom dan observasi langsung yang telah dilakukan masing-masing terdapat beberapa masalah, yaitu:

1. Tidak terintegrasinya kerangka kerja organisasi secara efektif

2. Penyelesaian laporan kinerja yang tidak tepat waktu

3. Kurangnya monitoring dari pimpinan terhadap kinerja $\mathrm{TI}$

4. Belum mengukur atau melakukan pemantauan terhadap pengendalian internalnya

Dalam penelitian ini peneliti akan menggunakan COBIT framework 4.1 (Control Objectives For Information And Related Technology) dimana konsep dasar kerangka kerja COBIT adalah bahwa penentuan kendali dalam TI didasarkan kepada informasi yang diperlukan untuk mendukung tujuan bisnis dan informasi yang dihasilkan dari gabungan penerapan proses TI dan sumber daya terkait. Khususnya pada domain Monitoring dan Evaluasi (ME) yaitu pada proses Monitoring dan Evaluasi Kinerja TI (ME1) adalah manajemen efektifitas kinerja TI membutuhkan proses pemantauan.

Proses ini mencakup pendefinisian indikator kinerja yang relevan, pelaporan kinerja yang sistematis dan tepat waktu, dan tindakan cepat atas penyimpangan dan domain Delivery dan support adalah membentuk program pengendalian internal teknologi informasi yang efektif memerlukan proses pemantauan dan pelaporan pengecualian kontrol, hasil penilaian mandiri dan ulasan dari pihak ketiga. Manfaat utama dari pemantauan pengendalian internal adalah untuk memberikan keyakinan yang berkaitan dengan operasi yang efektif dan efesien dan kepatuhan terhadap hukum dan peraturan yang berlaku. Pemantauan diperlukan untuk memastikan bahwa hal yeng benar dilakukan dan sejalan dengan arah dan kebijakan yang telah di tetapkan.

PTIPD Uin Suska Riau merupakan salah satu Unit Pelaksana Teknis (UPT) dimana pada awal berdirinya bernama Pusat Komputer (PUSKOM). Didirikannya pusat komputer saat itu berawal dari ide yang di susun dengan tujuan untuk menterjemahkan rencana strategis Uin Suska Riau yang terangkum dalam Rencana Induk Pengembangan Teknologi Informasi (RIPTI) untuk diharapkan dapat menjadi pusat kegiatan operasional dibidang teknlogi informasi, ikut serta dalam usaha peningkatan kualitas pendidikan, pengajaran dan penelitian maupun pengabdian kepada masyatakat. PTIPD UIN SUSKA RIAU resmi berdiri didasari oleh surat keputusan nomor: 201/R/2006 yang di tandatangani oleh Rektor Uin Suska Riau pada tanggal 27 juli 2006.

Hubungan antara pengukuran dan penilaian saling berkaitan. Mengukur pada hakikatnya adalah membandingkan sesuatu dengan atau atas dasar ukuran atau kriteria tertentu (meter, kilogram, takaran dan sebagainya), pengukuran bersifat kuantitatif penilaian berarti menilai sesuatu. Sedangkan menilai itu mengandung arti mengambil keputusan terhadap sesuatu yang berdasarkan pada ukuran baik atau buruk, sehat atau sakit, pandai atau bodoh dan sebagainya. Dan penilaian bersifat kualitatif. Mengukur adalah membandingkan sesuatu dengan satu ukuran (bersifat kuantitatif), menilai adalah mengambil suatu keputusan terhadap sesuatu dengan ukuran baik buruk (bersifat kualitatif), dan evaluasi 
meliputi kedua langkah tersebut di atas[2].

Menurut Information Technology Governace Institute terdapat 5 area yang diperlukan dalam Tata Kelola TI yaitu Keselarasan strategi, Bisnis dan strategi TI, IT Value Deliver, manajemen resiko, pengukuran kinerja dan manajemen sumber daya TI. Adapun yang menjadi area fokus dalam proses pengelolaan tata kelola teknologi informasi yaitu [3]:

1. Penyelarasan strategi (Strategic aligment)

2. Penyampaian nilai (Value Delivery)

3. Manajemen sumber daya (Resource Manajemen)

4. Manajemen Resiko (Risk Management)

5. Pengukuran Kinerja (Performance Measurement)
COBIT dikeluarkan dan disusun oleh IT Governance Institue yang merupakan bagian dari ISACA (Information Systems Audit and Control Asociation). COBIT pertama dikeluarkan oleh ISACF tahun 1996, pada versi kedua, COBIT merefleksikan suatu peningkatan sejumlah dokumen sumber, revisi pada tingkat tinggi serta tujuan pengendalian terperinci dan tambahan seperangkat alat implementasi, yang dipublikasikan pada tahun 1998. Pada versi ketiga COBIT, masuk ke penerbit baru yaitu IT Governance institute (ITGI). COBIT dapat diartikan sebagai tujuan pengendalian untuk informasi dan teknologi terkait dan merupakan standar terbuka untuk pengendalian terhadap teknologi informasi yang dikembangkan dan dipromosikan oleh Institut IT Governance

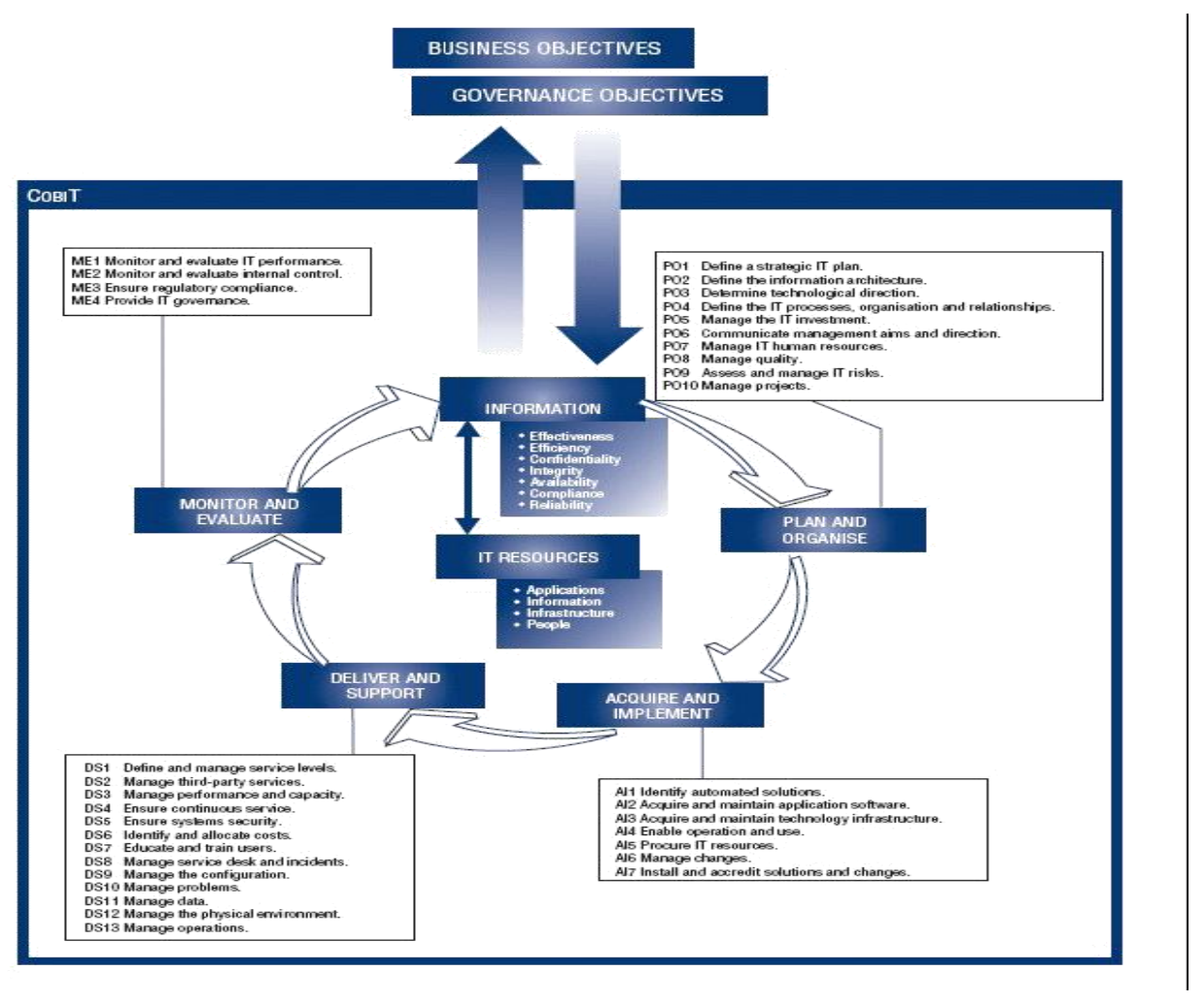

Gambar 1. Kerangka Kerja COBIT

Pada dasarnya kerangka kerja COBIT terdiri dari 3 tingkat control objectives, yaitu activities dan tasks, process, domains activities dan tasks merupakan kegiatan rutin yang memiliki konsep daur hidup sedangkan task merupakan kegiatan yang dilakukan secara terpisah. Selanjutnya kumpulan activity dan task ini dikelompokan ke dalam proses $\mathrm{TI}$ yang memiliki permasalahan pengelolaan TI yang sama dikelompokan ke dalam domains. COBIT diarancang terdiri dari 34 high level control objectives yang menggambarkan proses TI yang terdiri dari 4 domain yaitu: Plan and Organise, Acquire and Implement, Deliver and Support dan Monitor and Evaluate. Berikut kerangka kerja COBIT yang terdiri dari 34 proses TI yang terbagi ke dalam 4 domain 
pengelolaan sebagai berikut.

Delivery dan Support merupakan domain yang memberikan pandangan bagi pihak manejemen berkaitan dengan kualitas dan kepatuhan dari proses yang berlangsung dengan kendali-kendali yang diisyaratkan. Semua proses harus dilakukan penilaian secara regular untuk memonitor bagaimana kualitas dan kepatuhan dalam pelaksanaannya, meliputi faktor performansi pengelolaan, monitoring kontrol internal, serta kepatuhan terhadap aturan yang telah ditetapkan.

\section{Metodologi Penelitian}

Studi pendahuluan merupakan tahap awal dalam penelitian yaitu melakukan observasi dan survey secara langsung kelapangan untuk melihat permasalahan yang akan dijadikan sebagai bahan penelitian.

1. Rumusan masalah, batasan masalah, tujuan dan manfaat dalam penelitian

Pada tahap rumusan masalah apa yang akan dikaji dan menentukan batasan masalah untuk serta menjelaskan tujuan dan manfaat dalam penelitian ini.

2. Studi pustaka

Studi pustaka dilakukan untuk mencari referensi yang digunakan seperti buku - buku, jurnal, paper, e- book dan penelitian terdahulu.

3. Menentukan teknik dan alat penelitian

Peneliti menyebarkan kuisioner/ angket yang berisi pertanyaan-pertanyaan secara tertulis untuk diisi oleh sumber informasi (responden). Pada penelitian ini kuisioner yang disebarkan sesuai dengan sampel yang telah ditentukan yaitu sebanyak 3 orang responden. Kuisioner pada penelitian ini menggunakan pengukuran Maturity level.

Peneliti mengumpulkan data dengan cara mencari sumber untuk mendapatkan teori yang digunakan untuk mendukung penelitian yang dilakukan baik dari buku, jurnal, paper maupunliteratur literatur yang sesuai dan mendukung.

\section{Wawancara}

Wawancara merupakan satu teknik pengumpulan data yang pelaksanaanya dapat dilakukan secara langsung berhadapan muka dengan orang yang diwawancarai.

2. Observasi

Observasi merupakan kegiatan pemusatan perhatian terhadap suatu objek dengan menggunakan seluruh alat indera. Dengan demikian observasi dapat dilakukan dengan penglihatan, penciuman, pendengaran, peraba dan pengecap. Observasi dapat dibagi menjadi dua jenis, yaitu observasi sistematis dan observasi non sistematis.

\section{Hasil dan Analisis}

Pada tahap ini peneliti melakukan pengolahan data dari proses pengumpulan data. Data - data yang dioleh oleh peneliti dalam penelitian ini adalah:

\subsection{Analisis kondisi Existing}

Saat ini proses pengelolaan $\mathrm{TI}$ di C3 masih kurang efektif dan efesien penerapannya terhadap teknologi informasi. Kinerja TI yang ada saat ini masih kurang terintegrasi dengan sistem manajemen organisasi selain itu C3 juga di kelola oleh satu orang sebagai admin dan mahasiwa yang magang dan sering terjadi pergantian karyawan, akibatnya sistem kinerja yang ada saat ini belum mencapai target kinerja dalam organisasi, kinerja yang relevan, pelaporan kinerja yang tidak tepat pada waktunya. Maka dari itu perlu dilakukan pengawasan terhadap kinerja $\mathrm{TI}$ dan pengendalian internal yang terdefenisi dengan baik untuk memastikan bahwa hal yang benar telah dilakukan dan sejalan dengan arah dan kebijakan yang telah ditetapkan dan memberikan kepastian mengenai operasi dan kepatuhan sesuai perundang-undangan yang berlaku.

\subsection{RACI (Responsible, Accountable, Consulted, Informed)}

Dalam penelitian ini perhitungan responden berpedoman pada diagram $\mathrm{RACl}$ yang mana peran-peran yang didefinisikan pada diagram RACl adalah sebagai pemangku utama (Key Stakeholder) yang terkait secara lansung pada proses pengelolaan $\mathrm{TI}$ yang selanjutnya akan di diinterprestasikan pada fungsional struktur pada C3 Uin Suska Riau. Dan pimpinan yang berada pada 
posisi Accountable (pananggung jawab) yang akan menjadi responden dalam penelitian ini, karena pimpinan yang menduduki fungsi inilah yang bertanggung jawab untuk menyetujui dan menerima pelaksanaan proses $\mathrm{TI}$.

\begin{tabular}{|l}
\hline \\
ACTIVITIES \\
\hline Klasifikasi dan eskalasi prosedur manajem \\
\hline Mendeteksi dan merecord permintaan laya \\
\hline Klasifikasi, investigasi, dan diagnosa \\
\hline Penyelesaian masalah dan menutup masala \\
tingkat maturity untuk jawaban yang \\
\hline Mengupdate status kepada user \\
\hline Mengelola pembuatan laporan
\end{tabular}

skala tingkat maturity untuk jawaban yang disediankan pilihan :

1. 0-Non-Existent (Tidakada) :Tidak terdapat proses terkait sama sekali.

2. 1-Initial/Ad Hoc (Permulaan) : Tahap dimana organisasi telah menyadari perlunya pengelolaan $\mathrm{TI}$ tetapi belum ada proses standar yang harus dilakukan.

3. 2-Repeatable but Intuitive (Pengulangan) : Manajemen telah memiliki pola untuk melakukan proses pengelolaan berdasarkan pengalaman berulang yang pernah dilakukan sebelumnya. Prosedur belum terstandarisasi dan tanggung jawab proses tata kelola diserahkan kepada individu masing-masing.

4. 3-Defined

Process (Terdefinisi) : Organisasi telah menyadari dan mengetahui akan kebutuhan pengelolaan $\mathrm{TI}$,

\begin{tabular}{|c|c|c|c|}
\hline Functions & 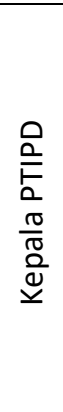 & 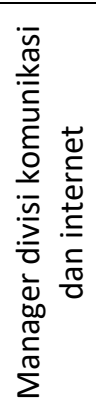 & $\frac{.5}{\frac{g}{0}}$ \\
\hline anan & C & C & $A / R$ \\
\hline informasi & 1 & C & $A / R$ \\
\hline & 1 & C & $A / R$ \\
\hline & 1 & C & $A / R$ \\
\hline & C & C & $A / R$ \\
\hline & C & 1 & $A / R$ \\
\hline
\end{tabular}

prosedur TI telah distandarisasi di dokumentasikan dan di komunikasikan melalui pelatihan

5. 4-Manage and Measurable (Dikelola) : Organisasi telah memahami pengelolaan $\mathrm{TI}$ di seluruh bagian pada tahap ini proses standar telah diterapkan secara formal dan terintegrasi. Manajemen mengawasi dan mengukur kinerja $\mathrm{TI}$ dengan prosedur, serta mengambil tindakan ketika proses tidak berjalan dengane fektif.

6. 5-Optimised (Optimal) : Proses dalam perusahaan telah disesuaikan dengan best practice, praktek terbaik berdasarkan hasil pengembangan secara terusmenerus dengan perusahaan lain.

Maturity level atau tingkat kematangan di dapat dari hasil perhitungan yaitudengan menghitung nilai masingmasing level Maturity Model dengan cara membagi jumlah jawaban dengan jumlah responden tiap proses $\mathrm{TI}$, rumus dituliskan sebagai berikut : 


Indeks maturity $=$
\begin{tabular}{|c|c|c|c|}
\hline \multirow{2}{*}{ Level } & Jumlah Jawaban & 3.3.DS8 (manage service desk) \\
& Compliance & Contribution & Value \\
\hline 1 & 0.41 & 0.33 & 0.14 \\
\hline 2 & 0.58 & 0.66 & 0.38 \\
\hline 3 & 0.38 & 1 & 0.38 \\
\hline 4 & 0.42 & 1.33 & 0.56 \\
\hline 5 & 0.38 & 1.66 & 0.63 \\
\hline \multicolumn{3}{|c|}{ Maturity Level } \\
\hline
\end{tabular}

Tabel 1. Hasil perhitungan domain DS8

Berdasarkan Maturity model pada proses DS8 yang diinterpresentasikan dalam bentuk scoring 0 sampai 5, C3 PTIPD Uin Suska Riau saat ini berada pada level 2 dengan nilai 2,09 yaitu Repeatable But Intuitive (Dapat Diulang) yang berarti proses pengelolaan kinerja $\mathrm{TI}$ sudah dikembangkan namun belum diterapkan oleh organisasi, metode yang digunakan selama ini belum sesuai dengan manajemen kinerja yang ada dan mulai melakukan identifikasi pelatihan dalam rencana kinerja. Pengelolaan kinerja $\mathrm{TI}$ pada C3 masih perlu melakukan pengembangan seperti laporan kinerja yang sistematis, dokumentasi laporan kinerja dan dan pegawai khusus IT dan untuk pengawasan kinerja $\mathrm{TI}$ secara umum..

\subsection{Proses Mengelola layanan service desk $\mathrm{C3}$}

Dalam penerapan kinerja $\mathrm{TI}$ di $\mathrm{C} 3$ berdasarkan hasil wawancara dengan beberapa staf yang ada di C3 yaitu dengan kepala PTIPD bapak Benny Sukma Negara, MT, manajer divisi komunikasi dan internet bapak Agus Surahmad, S.kom kinerja layanan C3 dianggap masih kurang efektif dan efesien karena dalam kinerja $\mathrm{TI}$ tidak terdapat operator khusus yang menangani problem $\mathrm{C} 3$, hal ini terkait ketersediaan SDM khusus untuk divisi C3. Selama ini operator c3 ditangani oleh mahasiswa/ siswa magang, hal ini mengakibatkan terjadinya mis komunikasi antar operator apabila terjadi pergantian. Untuk hal ini dilakukan transfer knowledge pada saat terjadi pertukaran operator. Proses yang mencangkup pendefinisian indikator kinerja yang relevan,pelaporan kinerja yang tidak sistematis, dokumentasi laporan kinerja yang masih kurang tersusun dengan baik dan tidak tepat waktu, proses pengawasan terhadap kinerja $\mathrm{TI}$ di $\mathrm{C3}$ masih kurang di perhatikan akibatnya kinerja yang ada di C3 masih banyak kekurangan.

Proses pengawasan terhadap pengelolaan kinerja TI dilakukan Pengawasan dilakukan lansung oleh kepala PTIPD bapak Benny Sukma Negara,MT dan manajer divisi komunikasi dan internet bapak Agus Surahmad, S.kom yaitu bagian kinerja TI yang ada di C3 Uin Suska Riau.

\subsection{Rekomendasi}

Dari hasil analisis diatas untuk mengatasi gap yang ada maka dibuatlah strategi informasi berupa rekomendasi pada setiap domain (IT proses) berdasarkan framework Control objectivitas for information related and technology (COBIT) 4.1 guna mencapai tujuan yang diharapkan.

Untuk memperkaya rekomendasi yang diberikan maka digunakan kerangka kerja ITIL V3. Sebelum melakukan rekomendasi dengan ITIL V3 terlebih dahulu dilakukan pemetaan terhadap COBIT 4.1 ke ITIL V3. Pada rekomendasi, kerangka COBIT membantu mendorong apa yang harus dilakukan, di dukung oleh layanan ITIL V3 sebagai strategi, dan ITIL panduan bagaimana untuk mencapai peningkatan yang di dukung oleh pengendalian dan praktek COBIT. Dari hasil pemetaan COBIT ke ITIL V3 kemudian diusulkan rekomendasi untuk setiap proses. TABEL 2 berisi rekomendasi strategi untuk mencapai target maturity level yang ingin dicapai. 
Jurnal Ilmiah Rekayasa dan Manajemen Sistem Informasi, Vol. 5, No. 2, Agustus 2019, Hal. 236-244 e-ISSN 2502-8995 p-ISSN 2460-8181

\begin{tabular}{|c|c|}
\hline COBIT 4.1 & ITIL V3 \\
\hline 1. Membuat framework pengkuran & 1. Membuat perencanaan identifikasi \\
\hline 2. Menyediakan staf khusus layanan & 2. Membuat kategori insiden; \\
\hline operator yang selalu aktif & 3. Membuat prioritas insiden; \\
\hline 3. Membuat SOP yang jelas mengenai & 4. Membuat diagnosis insiden; \\
\hline 4. Membuat pencatatan atas setiap & 6. Melakukan diagnosis dan investigasi; \\
\hline insiden yang muncul & Mendokumentasikan resolusi dan \\
\hline $\begin{array}{l}\text { 5. Mendokumentasikan setiap resolusi } \\
\text { dari C3 }\end{array}$ & $\begin{array}{l}\text { recovery; } \\
\text { 8. } \\
\text { Melakukan incident closure; }\end{array}$ \\
\hline $\begin{array}{l}\text { 6. Mengadakan training/ pelatihan } \\
\text { berkala bagi staf pengelola } \mathrm{C} 3\end{array}$ & $\begin{array}{l}\text { 9. Merencanakan pilihan menu } \\
\text { terhadap request fulfillment; } \\
\text { 10. Melakukan financial approval, } \\
\text { 11. Melakukan fullfiment }\end{array}$ \\
\hline
\end{tabular}




\section{Kesimpulan}

Berdasarkan analisis data dalam penelitian yang telah dilakukan, maka dapat disimpulkan sebagai berikut :

1. Pusat Teknolgi Informasi Dan Pangkalan Data (PTIPD) Uin suska riau telah menerapkan pengelolaan teknologi dan informasi rata-rata berada pada level 2 yaitu Repeatable but intutitive dari rentang nilai 0 sampai 5 . Artinya Pusat Teknolgi Informasi Dan Pangkalan Data (PTIPD) Uin suska riau telah mealkukan pengelolaan cukup baik.

2. Dari hasil pengukuran maturity level proses yang memiliki nilai maturiry level saat ini (as is ) 2,09 yaitu Repeatable but intutitive. Hal ini dikarenakan kerangka kerja dalam manajemen tidak terintegrasi dengan baik, kurangnya pengawasan terhadap kinerja TI yang ada, belum ada SOP yang baku, kurang SDM, pelaporan kinerja yang tidak sistematis dan pembagian tugas dan tanggung jawab yang tidak jelas.

3. Berdasarkan hasil analisis maturity level maka dibuatlah langkahlangkah usulan perbaikan terhadap pengelolaan kinerja TI Pusat Teknolgi Informasi Dan Pangkalan Data (PTIPD) C3 yang di prioritaskan untuk proses yang memiliki tingkat kesenjangan (gap) tertinggi yaitu proses pengawasan dan eveluasi kinerja TI (ME1)

\section{Referensi}

[1] IT Governance Institute (ITGI) (2011): COBIT® Process Assessment Model (PAM): Using COBIT® 4.1, IT Governance Institute, USA.

[2] IT Governance Institute (ITGI) (2009): CobiT® User Guide for Service Managerst, IT Governance Institute, USA.

[3] IT Governance Institute (ITGI) (2008) : Aligning CobiT® 4.1, ITIL®V3 and ISO/IEC 27002 for Business Benefit. IT Governance Institute, USA.

[4] IT Governance Institute (ITGI) (2008): COBIT® Mapping: Mapping of ITIL v3 With COBIT® 4.1, IT Governance Institute, USA.
[5] IT Governance Institute (ITGI) (2007): IT Governance Implemetation Guide, IT Governance Institute, USA.

[6] IT Governance Institute (ITGI) (2007): COBIT® 4.1, IT Governance Institute, USA.

[7] IT Governance Institute (ITGI) (2000): COBIT 3rd Implementation Tol Set, IT Governance Institute, USA.

[8] IT Service Management Forum (ITSMf) (2007): The Official Introduction to the ITIL Service Lifecycle, The Stationary Office, 65144, USA.

[9] Lipol, Lefayet Sultan, Jahirul Haq (2011): Risk Analysis Method: FMEA/FMECA in The Organizations. International Journal of Basic \& Applied Sciences IJBAS-IJENS vol: 11 no: 05, Sweden.

[10] Mendel, T., \& O’Neill, P. (2006). Implementing BSM: Keep The Big Picture In Mind If You Want To Reap The Full Benefit. Cambridge, MA: Forrester Research.

[11] Mira Musrini Putra (2010): Manajemen Masalah Dalam Pengelolaan Infrastruktur Teknologi Informasi (Studi Kasus Pada Itenas), Proseding Seminar Nasional Aplikasi Teknologi Informasi (SNATI 2010), Yogyakarta.

[12] Office of Government Commerce (OGC). (2007). ITIL V3 - Service Operation, The Stationary Office, 90-124, England.

[13] Office of Government Commerce (OGC). (2007). ITIL V3 - Service Improvement, The Stationary Office, 47-86, England.

[14] Noorhasanah,dkk, (2015), Evaluasi Tata Kelola teknologi Informasi berbasis Frameork COBIT 5. Seminar Nasional Teknologi Informasi dan Multimedia 2015. ISSN : 23023805

[15] Robert E. Stroud, (2010): Governing and Managing the Operational Environment With COBIT and ITIL, COBIT Focus Volume 4,

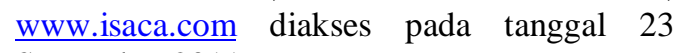
September 2011.

[16] Surendro, Kridanto (2009), Implementasi Tata Kelola Teknologi Informasi, Penerbit Informatika, Bandung, 198-300. 
[17] Sakam, R Djunaedi, Kridanto Surendro (2005): Usulan model information technology governance untuk sistem informasi sumber daya manusia. Proseding Seminar Nasional Aplikasi Teknologi Informasi (SNATI 2005), Yogyakarta.

[18] Silitonga, Tumpal Paradongan, Achmad Holil Noor Ali (2009) : Sistem Manajemen Insiden Pada Program Manajemen Helpdesk Dan Dukungan TI Berdasarkan Framework ITIL V3 (Studi Kasus Pada Biro Teknologi Informasi BPK-RI), Proceeding Seminar Nasional Teknologi Informasi MMT-ITS , Kampus ITS Sukolilo, Surabaya.
[19] Suradi, Agustinus, (2013) Analisis kematangan tata kelola informasi service desk dan insiden di Yayasan pangudi luhur Jogjakarta. Vol . VIII Nomor 24 November 2013 - Jurnal Teknologi Informasi ISSN : 1907-2430.

[20] Winniford, MaryAnne, Sue Conger, and Lisa Erickson-Harris (2009) Confusion in the Ranks: IT Service Management Practice and Terminology, Information Systems Management, 26: 153-163, Taylor \& Francis Group, LLC.USA.

[21] Wim Van Grembergen. (2004). Strategies for Information Technology Governance. Idea Group Publishing, Belgium. 